\title{
AFETO: O CICLO DO AMOR EM DEVANEIOS TRANSVERSAIS \\ ENTRE A POÉTICA PESSOAL E A DRAMATURGIA DO ATOR
}

\author{
Paulo César Sousa Dos Santos Junior \\ Paulo Roberto Santana Furtado \\ ETDUFPA
}

\begin{abstract}
Resumo
Este artigo é um memorial descritivo do processo de criação da cena "AFETO: amor fervente en(tre) trânsito ordinário" construído como parte da avaliação da disciplina "Dramaturgia do Ator" do curso Licenciatura em Teatro da Universidade Federal do Pará, no ano de 2017. Partimos de atravessamentos sobre os estudos de Gaston Bachelard no livro "A poética do devaneio" e apontamentos do trabalho sobre si presentes na "Dramaturgia Pessoal do Ator" de Wlad Lima, em uma confissão poética, onde o corpo homossexual, do intérprete criador desta cena, expõe suas vivências do ciclo do amor em devaneios transversais entre a poética pessoal e a dramaturgia do ator, desenvolvendo uma escrita autobiográfica narrada da perspectiva das personas criadas durante o processo, entendendo o devaneio poético autobiográfico na criação cênica como um ato necessário de empoderamento de si e resistência.
\end{abstract}

\section{Palavras-chave:}

Devaneio; Dramaturgia do ator; Poética pessoal; Corpo homossexual.

\section{INTRODUÇÃO}

Abro as portas do meu mundo para o seu deleite. Minha cartilha de devaneios está em tuas mãos. Aqui não serei uma cobaia, pois amo; Não congelarei meu coração, pois fervo; Não ficarei olhando da porta, pois entro sem olhar; Não terei medo de me aproximar, pois sem saber, já transito em você; Não temerei julgamentos, pois sou tão ordinário quanto teus sonhos mais sacanas. Não vou expor meus cálculos, os serei, pois o amor não é ciência, é devaneio. (Cena AFETO: Amor fervente en(tre) trânsito ordinário, 2017).

\section{Abstract}

This article is a descriptive memorial of the process of creation of the scene "AFETHE: fervent love in (ordinary) transit" constructed as part of the evaluation of the "Dramaturgy of the Actor" course of the Licensed Theater course of the Federal University of Pará, 2017. We start from cross-over on Gaston Bachelard's studies in the book "The Poetics of Daydreaming" and notes from his work on Wlad Lima's "Personal Actor's Dramaturgy" in a poetic confession where the homosexual body of the creative interpreter of this scene, exposes his experiences of the cycle of love in transverse daydreams between the personal poetics and the dramaturgy of the actor, developing an autobiographical writing narrated from the perspective of the people created during the process, understanding the autobiographical poetic reverie in the scenic creation as a necessary act of empowerment and resistance.

Keywords:

Daydream; Drama of the actor; Personal poetics; Homosexual body.

\section{Quem é o corpo que fala?}

Há várias formas de responder esta pergunta. A forma científica, metafísica, antropológica, histórica, anatômica, etc. Porém, o que nos interessa neste artigo não é escolher uma única forma de comunicar os acontecimentos, conceitos e atravessamentos do processo criativo aqui descrito, mas deixar o corpo que cria falar, entendendo que em nosso contexto poético, o corpo que fala é um corpo que confessa, direcionandose diretamente a você que lê. É um corpo poético fragmentado em cinco partes; e quem escolhe a 
forma de se comunicar é o fragmento deste corpo que será agenciado a responder as perguntas que surgirão a cada momento da escrita.

\section{Como é o corpo que escolhe?}

Este corpo, é um corpo que tem o seu lado psicológico e físico unidos em uma única palavra: corpo. Um corpo homossexual que tenta libertarse das amarras do pensamento heteronormativo que tem sobre ele próprio. É um corpo que grita nas narrativas cênicas que produz. Um corpo que não espera, apenas age, aguentando apenas três tentativas em qualquer relacionamento amoroso. Errou a primeira vez "tudo bem!"; errou a segunda, "complicado"; errou a terceira, "tchau, tchau!". Este corpo responde com rituais pessoais repetitivos e ordinários.

\section{Este corpo é fragmentado.}

Calma. Ele se explica:

No decorrer das pesquisas e experimentações cênicas, percebi que é "comum" para nós que residimos em um corpo homossexual nos sentirmos fora de contexto, ou fragmentados, pois somos corpos agenciados a apresentar fragmentos aceitáveis de si em cada lugar que frequentamos. Em minha liberdade poética, me fragmento nesta escrita, tal como me convencionaram a fazer no meu dia a dia. Uma ironia sobre nossos corpos que lutam para libertar-se.

\section{Que corpo é esse que escreve?}

Sou um corpo de 22 anos, jovem e ordinário, que se vê preso a um ciclo com as mesmas fases, porém que se renovam com rostos e nomes diferentes. Um corpo cansado, e subestimado em sua existência. Um corpo que tem este ciclo como Cicatriz Indutora ${ }^{1}$.

Sou um corpo, que se explora como seu próprio objeto de pesquisa. Este corpo homossexual, evidencia percepções sobre os Ciclos dos relacionamentos amorosos que viveu por meio das histórias pessoais revisitadas em perspectivas cênicas específicas para o trabalho do ator, utilizadas na montagem da cena solo "AFETO - Amor fervente en(tre) trânsito Ordinário", apresentada como parte da conclusão da disciplina Dramaturgia do Ator, do curso Licenciatura em Teatro da UFPA, ministrada pelo Prof. Msc. Paulo Santana, auxiliado pela Prof. estagiária Tânia Santos.
Meu corpo falará de amor, sexualidade, teatro e principalmente de afeto. E os três, são bem vivenciados quando nos valemos da intuição. Neste artigo, este corpo que confessa, também é intuitivo, partindo da perspectiva de que as metodologias e técnicas de encenação e atuação são as sustentações para nossos devaneios tornarem-se cenas, cênicas e cínicas. Importantes para a racionalização e comunicação do mundo que "Se forma no nosso devaneio, um mundo que é nosso mundo. E esse mundo sonhado ensina-nos possibilidades de engrandecimento de nosso ser nesse universo que é nosso..." (BACHELARD, 1988, p. 8).

Este corpo homossexual, percebendo suas cicatrizes protuberantes, resolve ressignificá-las como poéticas cênicas, estas cicatrizes não vêm de fora ou de longe, elas vêm de dentro, das vísceras, que remexidas despertam formas de fazer que já estão presentes na carcaça que envolve o

\section{Coração}

órgão que pulsa bombeando sangue para todo o corpo em um compasso eletrizante e uma intensidade que Ihe traz um significado ambíguo quando falamos de amor. Se o teu coração parar de bater a morte bate à tua porta, se o homem não amar algo ou alguém, a morte bate tua porta antes que seu coração pare de bater. Para escrever este artigo meu corpo teve que bater na porta de sua ancestralidade.

\section{MATERIAIS E METODOLOGIAS DESTE CORPO}

Em um breve recesso da Universidade que fica em Belém (PA), passei um período na casa de meus pais em Bragança (PA). Matar a saudade de meses sem vê-los e revirar as caixas que ficaram em meu quarto, cheias de poesias da minha adolescência e cartas que recebi de amores passados. Também, aproveitaria esta visita para escrever este e os outros tantos trabalhos acadêmicos acumulados. Não consegui. Ao conversar com meus pais sobre a solidão a qual me encontrava naquele momento, tive respostas que não mostravam interesse para que eu saísse desta situação. Por que eles preferiam que eu ficasse sozinho? Ao me questionar percebi o quanto que eu ainda estava impregnado por conceitos e ações que não representam meu corpo homossexual, entre elas, algumas convenções do amor a dois que não cabem em outros tipos de relação que não sejam 
heterossexuais, sobre as quais conversaremos nos próximos parágrafos.

Com a percepção do estado e contexto onde meu corpo-pesquisa estava inserido, me abracei na possibilidade de aproveitar essas caixas de lembranças, que estavam no meu quarto e na minha memória, para explorar os antecedentes a este momento, devaneando sobre meus amores, e principalmente, deixar-me experimentar, na prática, as palavras de Bachelard (1988, p. 7-8):

Notamos, aliás, que um devaneio, diferentemente do sonho, não se conta. Para comunicá-lo, é preciso escrevê-lo, escrevê-lo com emoção, com gosto, revivendo-o melhor ao transcrevê-lo. Tocamos aqui no domínio do amor escrito. Essa moda está acabando. Mas o benefício permanece. Ainda existem almas para as quais o amor é o contato de duas poesias [...] Para dizer um amor, é preciso escrever. Nunca se escreve demais. [...] Os devaneios de duas almas solitárias preparam a doçura de amar. Um realista da paixão verá aí apenas fórmulas evanescentes. Mas não é menos verdade que as grandes paixões se preparam em grandes devaneios. Mutilamos a realidade do amor quando a separamos de toda a sua irrealidade.

Interpretei-o de forma literal e comecei a devanear sobre minhas histórias de vida, e registrando-as em meu caderno de devaneios AFETO, dividindo-o em cinco partes: Amor - histórias afetuosas, críticas ao romantismo heteronormativo e aos finais felizes inalcançáveis; Fervente - homossexualidade, a contradição da fé e a descoberta do prazer; En(tre) Atravessamentos, precipitações e histórias rápidas; Trânsito - sobre as paixões passageiras, o rodízio de corpos e a marginalização históricosocial do corpo homossexual e de ações populares na comunidade gay; e Ordinário - Os momentos em que fui ordinário, as relações mais complicadas e os espíritos zombeteiros contemporâneos.

A cada história escrita neste caderno de devaneios, fatos reais eram distorcidos, viravam um mundo a ser desbravado com a minha empolgação e necessidade de reescrevê-los em minha memória. Eu mudava os desfechos, manipulava os fatos para que chegassem mais próximos de como eu queria que tivessem acontecido, ou apenas transcrevia poeticamente aquilo que me ensinaram estas experiências. Não medi esforços para ser sincero comigo mesmo, julgar menos e analisar mais. Porém não conseguia falar no presente, tudo era sobre o passado. Naquele momento meu corpo sentia-se distorcido, fragmentado tal como as partes do meu caderno de devaneios, como se as decisões, ações e conceitos incorporados até então não o representassem. Que corpo é esse que me veste? Como me olhar neste momento? 0 que resta de amor em mim?

Para que me sinta pleno e verdadeiro respondendo estas perguntas e pensando sobre este corpo nas próximas linhas deste artigo, também dividirei seu desenvolvimento tal como meu caderno de devaneios, explorando estes 5 fragmentos de meu corpo homoafetivo. Cada parte da escrita, desenvolve os pensamentos das 5 personas experimentadas durante o processo. São 5 partes de um corpo, confessando sua trajetória.

\section{AMOR}

Quando saí da casa dos meus pais em 2014, aos 18 anos, para morar na capital do estado, Belém, tive total apoio para estudar aquilo que realmente eu quero e acredito: O teatro. Mesmo sabendo das dificuldades do trabalho artístico em nosso país, não me via fazendo outra coisa. Coloquei a máscara da coragem e alimentei minha sede de fazer e ser arte.

Desde cedo, mesmo sendo muito tímido, me envolvia em tudo o que tinha relacionado a arte na escola. Ainda lembro da sensação estranha de quando aos 05 anos pisei pela primeira vez em um palco, na minha colação de grau do maternal. Nos anos seguintes sempre tendia para o teatro, seja em resultados de disciplinas, projetos das feiras pedagógicas, ou eventos dentro das escolas que estudei. Até que durante a sétima série, com 14 anos de idade, fui chamado para participar de um grupo de teatro da cidade, o Grupo de Teatro Espaço \& Arte, um grupo com 30 anos de história. Nesse mesmo período eu estava conhecendo o meu primeiro namoradinho, mas estava mais interessado e focado no teatro, queria fazer tudo da melhor forma possível, segundo os conhecimentos do poeta e diretor amador que nos regia naquele grupo. Em pouco tempo meu namoro acabou. Fiz pouco caso com este término, ainda não era assumido para a minha família e estava em processo de aceitação. Tenho certeza que foi nesse momento que eu me casei com o teatro, e todos outros homens pelos quais me apaixonei tornaram-se apenas amantes extraconjugais e passageiros. 

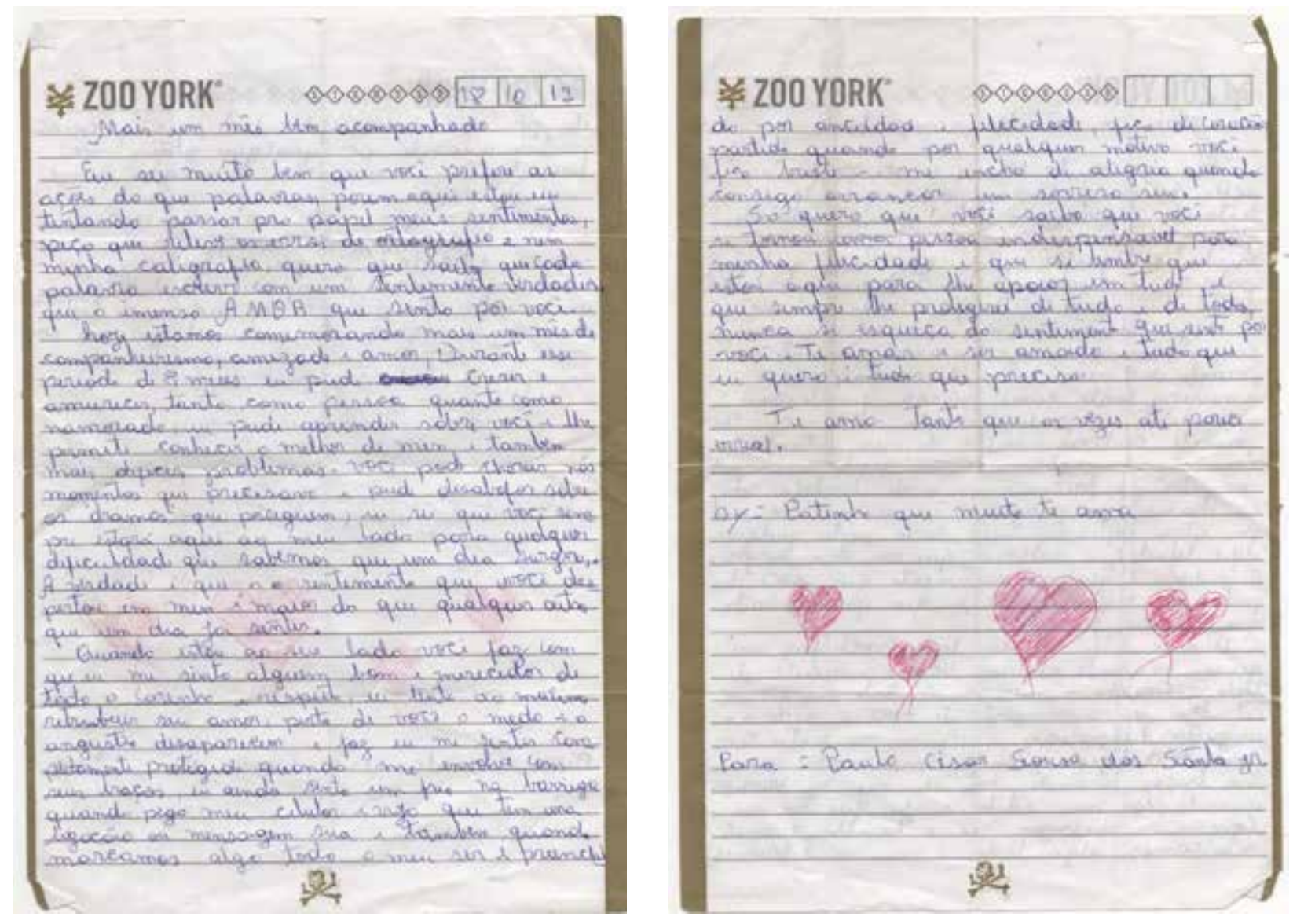

Figura 1 - Carta escrita pelo meu primeiro amor, recebida em 18 de outubro de 2012.

Ao escrever o caderno de devaneios AFETO pude me perceber internamente, fiz-me história, arte e poesia. Presenteei-me com uma nova visão sobre meu ser, dessa vez escritas em papel, diferente das escritas do corpo que a prática do teatro como ator proporcionou-me até então. Como um amante da vida, sempre tive vontade de ter um diário, mas uma grande preguiça de escrever me dominava, parecia-me pouco interessante falar sobre mim ou sobre aquilo que eu sentia, a quem poderia interessar? Com a minha entrada na universidade e o aprofundamento nos estudos sobre atuação, encenação e direção, entendi não apenas a importância desta prática, mas como minha escrita poderia ser em sua plenitude: Poética.

Na conclusão prática da disciplina Dramaturgia do Ator, apresentei uma cena que leva o mesmo nome do meu caderno de devaneios. Os atravessamentos que as escritas deste caderno trouxeram para minhas ações e percepções do cotidiano deste corpo, são o foco principal desta cena - suprimidos em míseros 12 minutos - onde cada palavra escrita no caderno de devaneios, foi sentida e exposta na execução das partituras corporais e na síntese que a ação cênica me possibilitou. Assim, tendo o preenchimento de sentido que o ator solista necessita ao trabalhar suas personas.

Esse estado de entrega me revigorou de tantas formas que continuo escrevendo as minhas histórias no meu caderno de devaneios, que sem dúvida ainda terá muitas páginas escritas. Sempre acontece algo que se encaixa em algum de seus eixos, como se minha personalidade se dividisse tal como este caderno. Arrisco-me a dizer que a partir dessa prática estou começando a entender o que é de fato amar. $O$ que mais me instiga é que quanto mais me nego a racionalizar o amor, mas necessito entendê-lo e senti-lo.

Durante a cena AFETO apresentada no dia 23 de agosto de 2017, em um momento pontual fiz a leitura desta carta, que é um dos meus maiores tesouros afetivos. Neste momento a emoção era plena, sem qualquer tensão interpretativa forçada. Era o ator em estado performativo, no qual a persona ${ }^{2}$ da ação 
cênica confessava a intimidade sentimental deste corpo para o público. Era a minha realidade recortada e ressignificada a serviço da cena, pegando atalhos no Rizoma Deleuziano, na multiplicidade de sentidos, " um modelo de resistência ético-estético-político, trata-se de linhas e não de formas. Por isso o rizoma pode fugir, se esconder, confundir, sabotar, cortar caminho [...] Aumenta-se as conexões, em linhas de intensidade, sem fechar as estruturas"3, tal como esta potencialização do ator em estado de entrega, desbravando-se sem conversões ou limites.

\section{FERVENTE}

Essas histórias de amor deixam cicatrizes que nos atravessam para além de alegria ou da dor, são essas experiências que nos fazem buscar novos amores e persistir em continuar a sina do ser humano: a coletividade. O que seria de nós sem o ato de amar? Seja o amor por uma pessoa, um objeto ou uma ação. Amo o teatro, em contrapartida apenas me apaixono pelas pessoas. E é necessário que isto fique claro, pois, como falar de dramaturgia do ator, sem falar da realidade deste artista, e o contexto temático da obra a ser montada em relação aos seus desejos? Como disse Wlad Lima (2004, p. 49) na Dramaturgia Pessoal do Ator:

Exposto os intercessores deste criador, é preciso conseguir revelar os princípios de sua criação. Estes princípios são aquilo que, de maneira alguma, ele pode abrir mão. São pensamentosações, isto é, pensamentos que movem as ações, em todas as atividades cotidianas, principalmente, as experimentações criativas.

Em estado de devaneio forjei minhas histórias na escrita literal, no papel, para que em seguida as escrevesse em meu corpo. Uma colagem de recortes oriundos da memória deste corpo. o devaneio começa a ganhar forma por meio das ações, neste processo de experimentação onde o ser exposto em cena, encontra-se entre o véu cênico ${ }^{4}$ e o voyeur que o observa, deleita-se e julga-o, tal como você leitor.

Uma lembrança que veio a minha mente ao começar as experimentações cênicas, foram os momentos de irracionalidade da adolescência, quando a minha vida era um quadrado no qual eu estava no centro, já abraçado ao teatro, com algumas garrafas de aguardente nas mãos, tomado pela culpa que estar com alguém do mesmo sexo

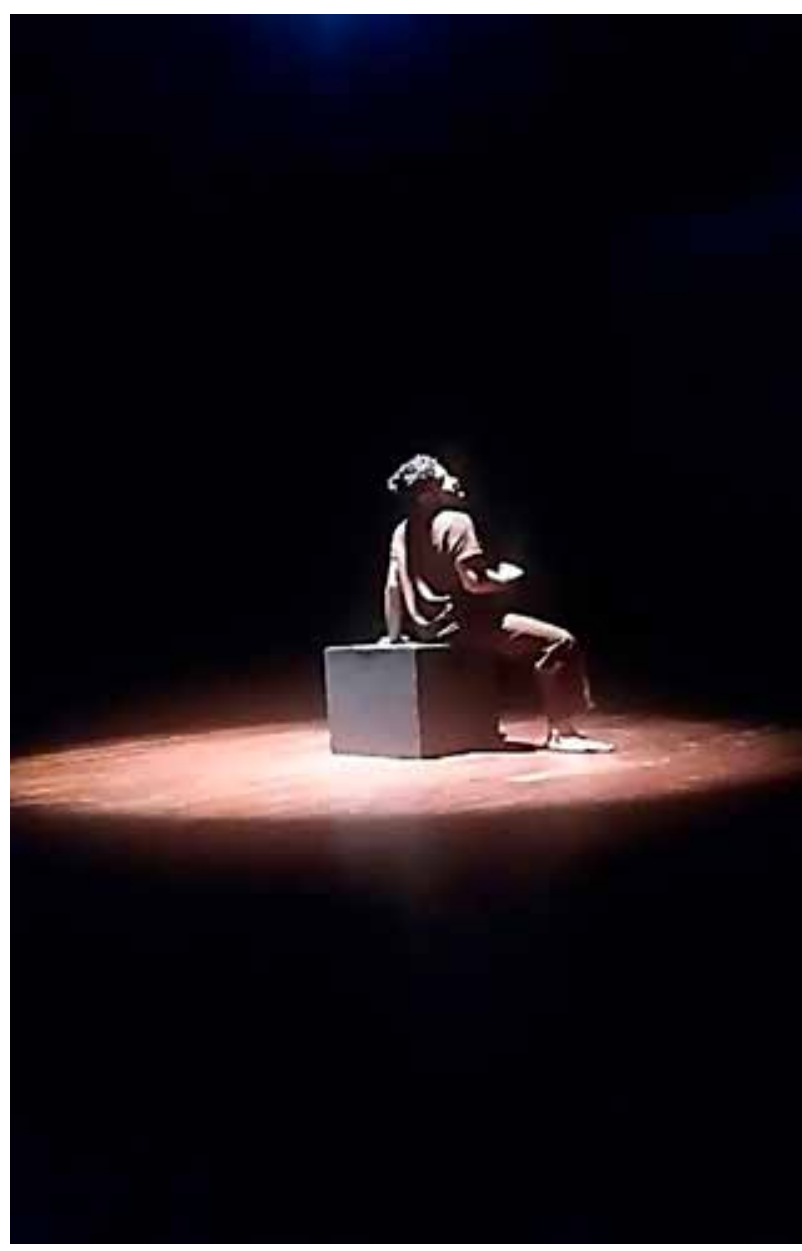

Figura 2 - Registro da cena AFETO, 23 de agosto de 2017.

me causava. A culpa, medo e preocupação com meu pai, minha mãe e deus.

Por muito tempo, proibidos de dizerem o nome, não haveria nestes amores muito tempo para a fala, para a discussão da relação, para a elaboração discursiva, para a invenção narrativa da relação afetiva. Tendo à disposição fragmentos de um discurso amoroso que não thes dizem respeito, elaborado em torno das relações afetivas heterossexuais, os amantes homossexuais sofreriam de uma espécie de afasia, por se sentirem sempre deslocados, fora de lugar, diria mesmo ridículos naquele discurso. (ALBUQUERQUE, 2010, p. 45).

No artigo Amores que não têm tempo: Michel Foucault e as reflexões acerca de uma estética da existência homossexual, Durval Albuquerque Júnior, retrata a estética presente nas obras criadas por artistas homossexuais a partir dos pensamentos de Michel Foucault. Neste artigo é exposto o contexto histórico-social da marginalização das relações homossexuais, as quais tendem por narrativas do ato sexual e 
de relações carnais, pela falta de tempo que o medo e a não aceitação provocaram nas relações homoafetivas de um passado não tão distante, e que ainda reverbera nos corpos homossexuais da juventude contemporânea, pois percebi que por toda a adolescência o amor que vivenciei, não contemplava a materialidade e essência do meu corpo e seus desejos reais. Tempos depois descobri que era viciado nessa masturbação sentimental.

Partitura 1 - Sentado no canto direito posterior do caixote que fica ao centro do foco, de costa para o público. Respiração ofegante. Faz movimentos de Masturbação. É surpreendido por sua mãe batendo na porta do quarto, porém não para de masturbarse. Fala como se estivesse dialogando com sua mãe. _ Oi mãe? O que foi?

_ Eu? Bem; Eu tô estudando!

- Preciso de muita concentração aqui. Não dá pra sair do quarto.

_ Fala que eu não tô.

_É quem? Para de masturbar-se.

_ O que ele quer? Apreensivo, vira-se para a plateia. _ Eu não tenho mais nada dele aqui.

- Não! Não deixe ele entrar. Minha porta está trancada pra ele.

(Trecho da cena Afeto: amor fervente en(tre) trânsito ordinário, 2017).

No momento exposto acima, a representação da masturbação sentimental é mimetizada em uma partitura corporal, ganhando um caráter cênico, saindo da pré-expressividade do devaneio sobre o corpo adolescente que me vestia, para tornar-se escritura cênica. o caráter cômico desta ação física acontece com a exposição da intimidade que permeia a situação encenada. Ridícula, aprofundando-se no rancor e imaturidade desta persona na adolescência. Este corpo que descobre sua sexualidade, é o que é amedrontado a renegá-la.

\section{(EN)TRE}

Nas demais partituras da cena, perceberemos esta mesma essência, porém com outras densidades de ação, que encadeiam as nuances de temperaturas na encenação do trabalho do ator solista. Segundo Renato Ferracine (2001, p. 88) no livro $A$ arte de não interpretar como poesia corpórea do ator:

Podemos dizer que a ação física é a passagem, a transição entre a pré-expressividade e a expressividade. Ela corporifica os elementos préexpressivos de trabalho, e como já dito, é o cerne, a base e a menor célula nervosa de um ator que representa. É por meio dela que esse ator comunica sua vida e sua arte.

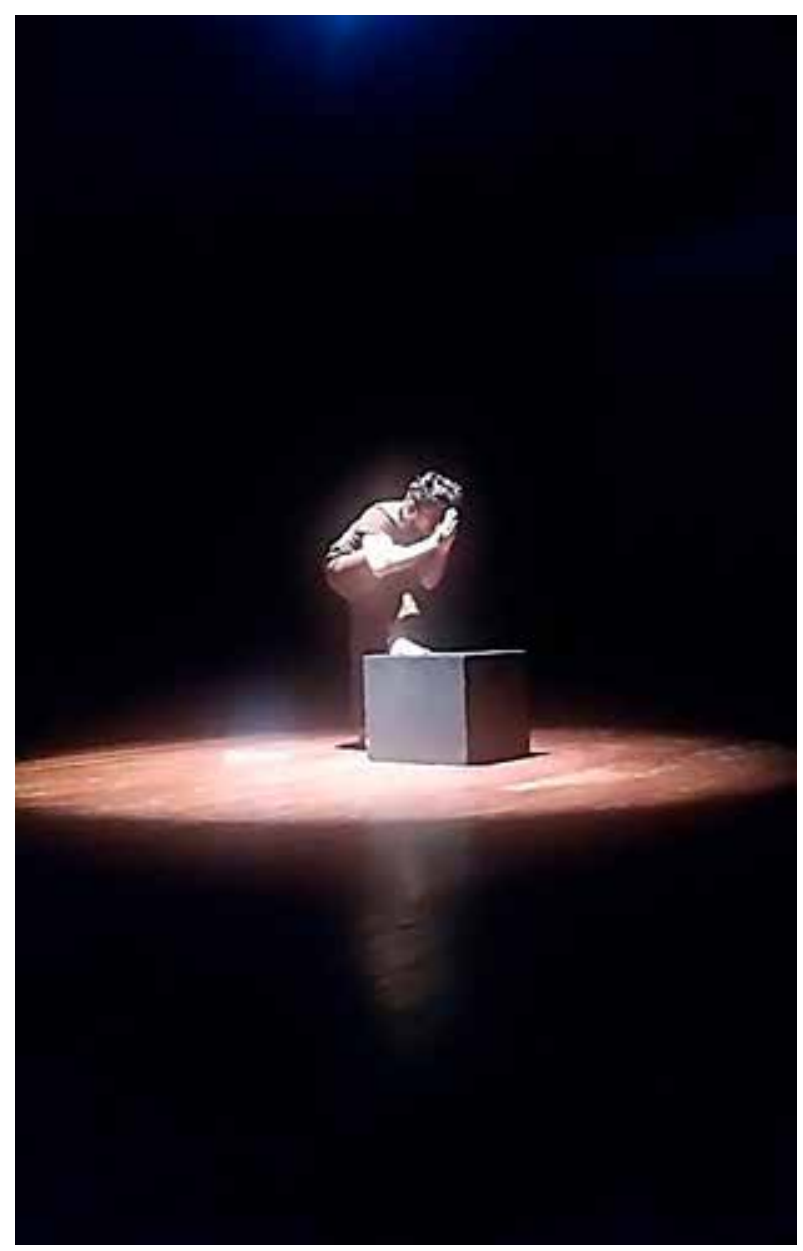

Figura 3 - Registro da cena AFETO, 23 de agosto de 2017.

A partir do devaneio poético sobre minhas experiências de vida, consegui entender meu corpo e suas condições dentro da cicatriz o ciclo do amor - temática principal deste processo. As ações físicas executadas no trabalho atoral ao serem organizadas formam as partituras corporais, que consequentemente, estabelecem a narrativa visual, externa, da escritura cênica. Sendo uma síntese das escritas e reflexões produzidas.

Na cena, criei 5 partituras, que executei por diversas vezes, sendo que em cada repetição, mudava a velocidade, o peso, expansão ou a densidade do movimento, e consequentemente alterava o seu sentido de acordo com a temperatura necessária naquele momento. A base deste trabalho vem do estudo dos fatores do movimento de Rudolf Laban, que analisava os "aspectos espirituais, mentais e emocionais do movimento" onde para experienciá-los plenamente é necessário ativar o "corpo, a mente e o espírito" (RENGEL, 2003, p. 16). 
O espírito ativado, na concepção de Laban seria o sentido ou a origem do movimento, porém dentro do espírito da persona que era exposta na cena neste momento, existia um rancor e necessidade de perdão. Não de pedir perdão, de concedê-lo ao ser que é tido como justificativa para o preconceito de muitos seres brutos e intolerantes: deus.

Não. Os religiosos não são o objeto deste rancor, pelo contrário, admiro sua fé. A questão que o alimenta é a má utilização do sentido do amor. O amor platônico, que se transformou na metafísica, base do monoteísmo cristão que rege nossa sociedade ocidental. Esse amor de deus, muitos marginalizados não conhecem, ou melhor, não sentem.

\begin{abstract}
Partitura 3 - Ao lado esquerdo do caixote - Com a perna esquerda em cima do caixote, tronco curvado e mãos juntas, em estado de reza. Representação do perdão.

Não esperarei que meus desejos se realizem, os farei reais. Não farei mais preces para que olhes de novo pra mim. Hoje meu corpo é pleno em si mesmo. (olhando para o público) Meus joelhos só se dobrarão novamente quando deus fizer as pazes comigo, pois eu não devo nada a ele.
\end{abstract}

\section{O CORPO GRITA}

Os seres de má fé que proclamam palavras brutais e agem como monstros medievais, em nome de um deus ditador e fiscal de nossos desejos, não têm o meu respeito, e carregam a culpa de todo o rancor que guardo em minha alma. Do rancor que me faz lutar todos os dias de minha vida contra uma depressão e ansiedade sufocantes. Mesmo tendo a consciência que meu corpo é livre, corruptível, não santo, aberto e afetuoso. Derramo-me entre braços que não conheço, e principalmente nos braços de quem bem me quer. 0 corpo que apresento neste momento da cena é o mesmo que carrega estas cicatrizes, e que a cada dia se risca com mais escrituras internas e externas tentando reafirmar sua importância e necessidade de GRITAR. Ficar sem fôlego.

\section{TRÂNSITO}

[...] uma prisão ou um deus. Não tem metade. Ou senão a metade é um picadinho, uma anatomia, um esboço, e nada disso dá em corpo. O corpo é um cadáver ou é glorioso. o que o cadáver e o corpo de glória compartilham é o esplendor radiante imóvel: definitivamente, é a estátua. O corpo se consuma na estátua. (NANCY, 2012, p. 45).

No caso da cena AFETO, essa estátua seria a síntese autobiográfica que as partituras corporais expressam, sobre a essência do empoderamento de si. A junção e repetição destas partituras ganham no decorrer da cena um fluxo contínuo que representa o ciclo do amor vivenciado por este corpo. A fluidez de imagens em trânsito são as cicatrizes expostas na cena. O fluxo estabelecido neste momento abrange diversas acontecimentos da memória deste corpo. A persona ofegante e extremamente presente e entregue a ação cênica, desenha um círculo, essa forma geométrica sem início ou fim. A encenação criada a partir destes experimentos, este círculo, torna-se - eixo transversal entre a poética pessoal e a dramaturgia do ator.

O ritual, o ciclo está sendo revivido neste momento, o êxtase provocado toma conta da cena. Evidenciase a capacidade cênica de organizar o caos, seja este interno ou externo, vomitando-o na fronte da plateia, que insiste em dar um sentido ao que acontece sob seus olhos. Rompe-se o véu. O discurso agora é direcionado aquele que antes apenas assistia confortável o sofrimento, a exaustão e a (des) regularização do meu ser. Provoco-os, xingo-os, rompo seus pudores, tudo isto em um devir Artaud:

[...] que observou que as normas e os padrões estéticos rígidos do teatro tradicional traziam elementos inibidores para o desenvolvimento de novas linguagens teatrais e para a vivência de novas experiências cênicas, particularmente aquelas vinculadas a novas expressões do corpo e da voz. Tais barreiras são oriundas, principalmente, da herança do próprio teatro europeu, que torna a representação cênica tradicional apenas imitação, ou seja, a realidade ficcionada limita as ações das realidades na cena do teatro e rechaça o universo ficcional. (FERNANDES, 2001, p. 70).

Os textos ditos nesse momento, carregam a crueldade deste homem que após passar por momentos de desrespeito, agora julga; Após entregar-se plenamente sem ser valorizado, agora amedronta aqueles que antes eram motivo de felicidade; $\mathrm{E}$ após despejar sua inocência na lama, lambuza-se nela como um porco. Transporto-me por alguns instantes para o momento em que me libertei de um amor possessivo, um daqueles que eu deixei pelo caminho na terceira tentativa. Os xingamentos proferidos para a plateia, eram os mesmos que proferi para aquele que tanto pisou, cuspiu e abusou do meu afeto.

A dor do desprezo entra no peito como uma estaca afiada. Já a senti, e já provoquei esta dor, todas vezes que disse "Eu te amo" e logo em seguida saí 


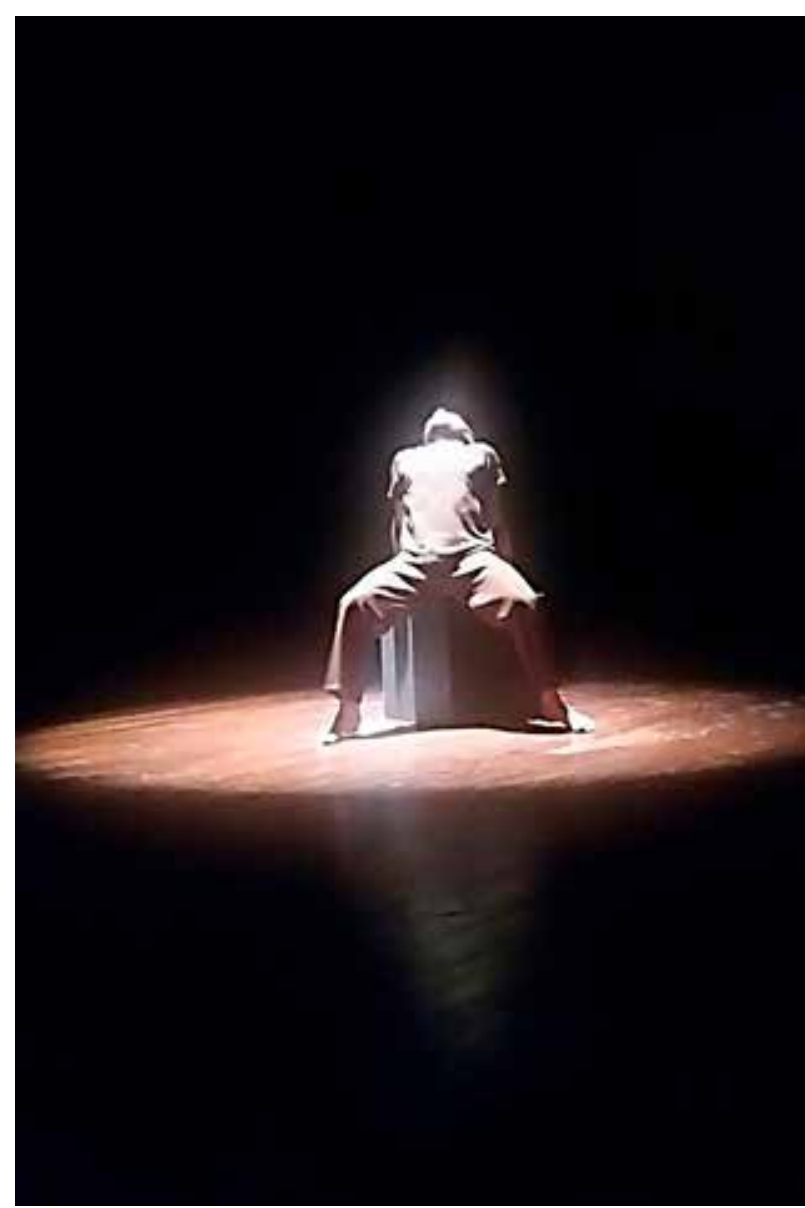

Figura 4 - Registro, 23 de agosto de 2017, cena AFETO.

correndo me distribuindo em doses secas de gozo amargo. Crueldade que não pratico mais (por enquanto). Mas que me atravessa e transporta para os momentos em que gozei ao lado do amor, com restos de outros caras pelo corpo. Um trânsito de corpos, pura libertinagem, a qual eu não inventei, sempre existiu, é a sina do corpo homossexual marginalizado, seja ele afeminado, passivo, ativo, versátil, heteronormativo, que se aceita ou não, todos são corpos marginalizados, alguns muito mais e outros muito menos, mas são marginalizados. Essa marginalização só mudou de roupa, mas ainda dissemina-se facilmente, em nossa era tecnológica e do encurtamento de distâncias; da virtualidade; dos aplicativos que prometem um vício disfarçado de amor.

Partitura 2 - Pula no canto direito frontal do caixote - Abre as pernas, escora-se sobre o caixote, cabeça cai para trás. Representação do prazer.

- Não guardarei meu corpo em altares santos. Não me renderei às convenções dos hipócritas. Me distribuirei segundo meu próprio desejo de paus, pais, paz.

\section{ORDINÁRIO}

Hoje, não me sinto mais o garoto do interior que veio para a capital em busca de realizar um sonho. Essa inocência estereotipada foi jogada no lixo junto com todo o meu medo de errar; o medo de falar; o medo de me expor; o medo de ter medo. Hoje, quase no final do meu curso de licenciatura em teatro não tenho medo do ridículo, ou que zombem de mim - fique à vontade caro leitor - na verdade sou o espírito zombeteiro da minha própria vida. Sinto-me pela primeira vez em minha vida, vivo. Essa confiança não está sendo construída com facilidade, pelo contrário, o suor escorre todos os dias no meu rosto a cada bateria de ensaios. A dor na perna após um alongamento mal realizado por puro cansaço faz eu me sentir um masoquista. Distribuo-me, mas não me prostituo. Melhor a dor do pouco público, do que a da consciência pesada. E agencio-me sabendo que:

Agenciar é o verbo que orienta a análise do fazer atoral [...]. O ator tem à sua disposição toda a realidade, para, com ela, estabelecer uma simbiose. A realidade, já disse Deleuze, é multiplicidade. Repito que é bem diferente de entendê-la como múltipla. É necessário substanciá-la: multiplicidade. O teatro sendo realidade inventada, precisa inventar as suas multiplicidades. Os atores precisam inventar acontecimentos, conectarse com acontecimentos - e estes, de diferentes naturezas e não apenas lingüísticos - para vir a ser, tornar-se, estar em devir, em movimento. Construir mapas com múltiplas entradas para esta invenção, que não é jamais imitação, nem interpretação, é experimentação. (LIMA, 2004, p. 36).

E neste contexto, jogo-me na mesma necessidade de brincar que tinha em minha infância. Invento, recorto, aproveito-me e ainda empresto minhas histórias pessoais, para produzir teatro. Aqui, fui extremamente autobiográfico, confesso que após toda esta experiência, eu necessitava desta confissão poética, que eu sei que te tocou de alguma forma, e lhe fez chegar até o final da leitura deste (des)artigo.

Mas não se engane comigo, em contrapartida a esta confiança interna que me contempla nestas linhas finais, ontem quebrei mais um coração. É-me curioso como é fácil quebrá-lo. Curioso também como não consigo mais sentir remorso por isso. E mais forte ainda saber que já fui idêntico a este garoto que teve a (in)felicidade de me encontrar, entregando seu coração ao primeiro que the deu um sorriso e afeto. Falta-Ihe calma, como um dia 


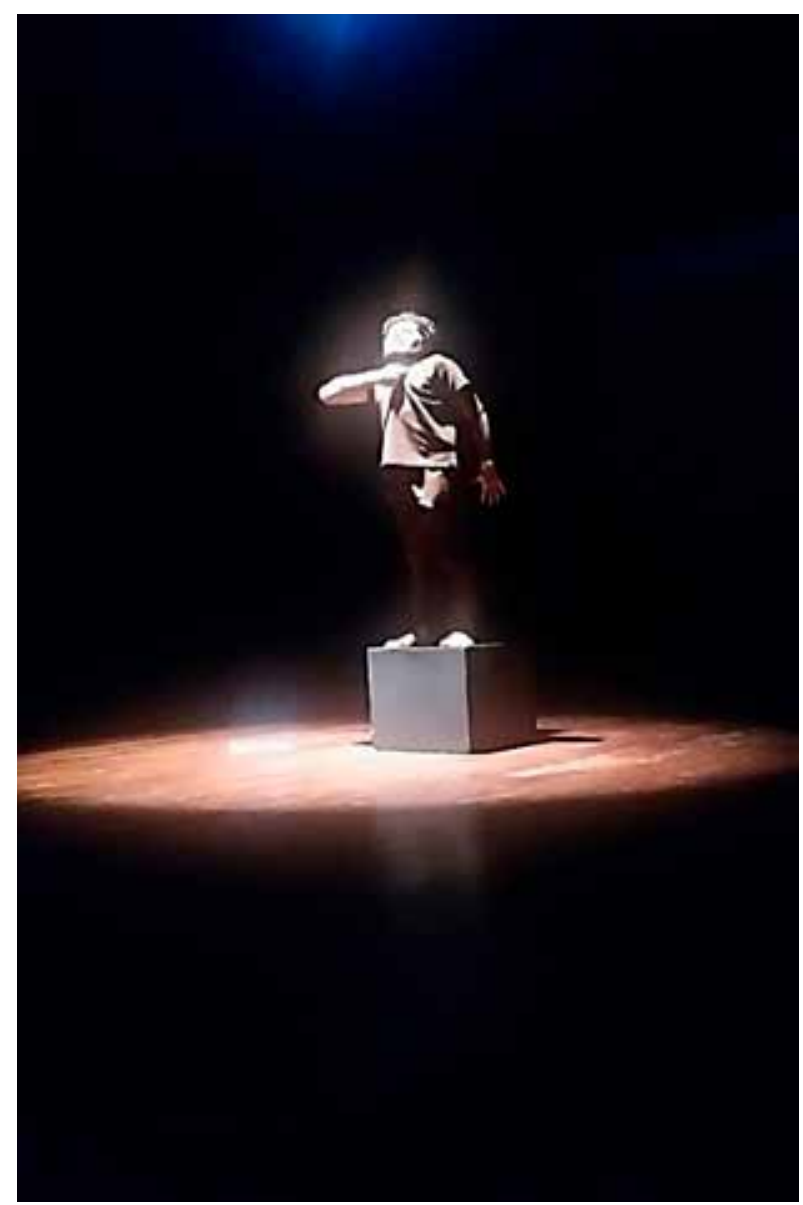

Figura 5 - Registro da cena AFETO, 23 de agosto de 2017.

também me faltou. Sobra-Ihe vida, como hoje não me sobra mais, pois aproveito-a até as bordas.

Os atravessamentos da disciplina Dramaturgia do Ator para este corpo homossexual são inúmeros, para além da cena, e me fizeram perceber o quão, hoje, sou um ordinário. E que bom que me encontro neste estado. Agora sou um ordinário consciente, posso ser mais responsável com os meus sentimentos e os sentimentos alheios. 0 coração que quebrei, por exemplo, não foi por mentiras, e sim por extrema sinceridade de saber que o amor só é pleno quando sentido dos dois lados do muro. Que o teatro só é teatro, quando fingimos ser - fica ao seu critério escolher o que é real e o que é fingimento dos fragmentos do corpo tema desta escrita - E quanto ao ator que remexeu, analisou e ressiginificou toda sua trajetória em prol de uma cena que expusesse sua principal cicatriz, afirmo que nunca mais pisará no palco sem sentir ou receber AFETO.

Partitura 4-Sobe no caixote-corpo ereto, massageia o peito esquerdolcoração. Representação do amor.
_Não negarei o pulsar do meu coração e muito menos suas cicatrizes. Apenas o guardarei na mesma geladeira onde deixaste o teu. E mesmo que o teu coração continue lá por toda eternidade, eu sei que um dia o meu voltará a pulsar. Eu não pertenço ao meu passado, o meu passado me pertence!

\section{NOTAS}

01. Cicatriz Indutora é a instigação base de todas as cenas desenvolvidas pelos alunos da disciplina; consiste na percepção e exploração de uma cicatriz sentimental, ancestral ou/e física do atuante, como apêndice da criação de sua cena/performance.

02. Nesse caso a persona seria a expansão da personalidade do ator através das ações físicas e representativas desenvolvidas na cena.

03. Disponível em: <https://razaoinadequada. com/2013/09/21/deleuze-rizoma/>. Acesso em: 06 set. 2017.

04. Para Jerzi Grotowski o que diferencia o ator do personagem é o Véu que o ato cênico coloca nos olhos da plateia. $O$ ator é ele mesmo realizando ações orgânicas oriundas de impulsos reais. O público é que o vê como personagem. Ele não é, realiza.

\section{REFERÊNCIAS BIBLIOGRÁFICAS}

ALBUQUERQUE, Durval. Amores que não têm tempo: Michel Foucault e as reflexões acerca de uma estética da existência homossexual. Revista Aulas: Dossiê Estéticas da Existência, UNICAMP, 2010.

BACHelard, Gaston. A Poética Do Devaneio. São Paulo: Editora Martins Fontes, 1988.

FERNANDES, Edson. A voz e o corpo: linguagem, estética e complexidade para uma reflexão no teatro de Antonin Artaud. Eccos Rev. Cient., São Paulo, n. 2, v. 3, 2001.

FERRACINE, Renato. A arte de não interpretar como poesia corpórea do ator. São Paulo: Editora Imprensa, 2001.

LIMA, Wlad. Dramaturgia pessoal do ator. A história de vida no processo de criação de Hamlet - Um Extrato de Nós com o Grupo Cuíra em Belém do Pará. Dissertação (Mestrado em Artes Cênicas) - Universidade Federal da Bahia, 2004. 
NANCY, Jean-Luc. 58 indícios sobre o corpo. Rev. UFMG, Belo Horizonte, v. 19, n. 1 e 2, p. 4257, jan./dez. 2012.

QUILICl, Cassiano. ARTAUD e a nostalgia do rito.

Revista Olhar, ano 3, jan-dez/2001.

O Treinamento do Ator/Performer: Repensando o "Trabalho Sobre Si" a Partir de Diálogos Interculturais. Revista Urdimento. Florianópolis, v. 2, n. 19, novembro de 2012.

RENGEL, Lenira. Dicionário Laban. São Paulo: Annablume, 2003.

\section{SOBRE OS AUTORES}

Paulo César Sousa Dos Santos Junioré Graduando da Licenciatura em Teatro e estudante do curso técnico em ator, ambos da Escola de Teatro e Dança da UFPA. Coordenador do Zecas Coletivo de Teatro.

Paulo Roberto Santana Furtado é Prof. Msc. da Licenciatura em Teatro da UFPA, coordenador da Lic. Teatro PARFOR e diretor do Grupo Palha. 